\title{
The Effectiveness Strategies for Students with Reading Challenges: New Frontiers
}

\author{
Ayman Alamri, lecturer ‘Prince Sattam Bin Abdulaziz University, Ph.D. Candidate at Duquesne University, \\ aa.alamri@psau.edu.sa \\ Siddiq Ahmed , Ph.D Special Education, Special Education in Prince George County Public School, Maryland, \\ The Founder of The Wise Thought Foundation, Non-Profit Organization, Maryland \\ siddiqme.siddiqahmed@pgcps.org
}

\begin{abstract}
This paper identifies a range of challenges that students with reading disabilities are made to encounter in educational settings. The paper draws on the relevant literature through annotated bibliography, considering studies on oral reading fluency initiatives and interventions towards communicatively competent learners. The paper's main trajectory of examination is a set of eight articles, of which five are experimental, two correlational, and one developmental. These articles, as my paper shows, underline reading fluency in educational institutions, where language teachers should be able to provide multiple reading strategies and interventions in order to enhance the reading fluency of students. Concluding with suggestions that are applicable to teachers and students, this paper asserts that no one single branch of knowledge can wear a single hat, and therefore that we need to connect with, not to ignore, researchers who work in the concerned area.
\end{abstract}

Keywords: Bibliographic Analysis, Oral Reading Fluency (ORF), Reading Challenges

Received: 04.12.2020 $\quad$ Accepted: 12.01.2021 $\quad$ Published: 03.02.2021

\section{INTRODUCTION}

Every learning institution must probably contain some children or students who have various types of learning disabilities. Reading fluently and getting the basic skills to read are very difficult for children (Rubin, 2016). Every teacher in his/her career meets learners, who have learning disabilities, and teaching them becomes hard. Teachers must, then, find various ways of teaching them so that they can realize a proper educational assessment on the affected children. The topic here is on how to assess students with learning disabilities, particularly in relation to reading as a skill. Learning disabilities refer to disorders that are heterogeneous and that may be manifested through difficulty in reading, listening, reasoning, and speaking among others.

The topic of assessment of reading fluency is significant to the field of special education because of various reasons. The ability to read with fluency is important, as it connects the comprehension of terms with understanding. It helps in finding out reading proficiencies of students in the classroom, as it focuses on the component of 'Response to Intervention' (Piper \& Zuilkonski, 2015). Because special education involves people or learners with special needs, by engaging them in fluent oral reading, it may be a way to enhance or improve how the learners can comprehend the texts being read. Based on the quality of the reading instruction, teachers will also identify students at their different degrees of special needs. Fluency in oral reading will enhance students with learning disabilities academic capacity.

Evaluation and diagnosis in special education is the cornerstone; precisely because, the individual educational plan cannot be built without the use of an assessment that helps identify the strengths and weaknesses of a student. In the field of education, many assessments are used, which differ according to the method of measurement. Therefore, in this synthesis paper, some studies which measure fluency in reading will be critically analyzed.

Fluency measurements of precision and speed were also suggested to mediate the association of encoding with reading comprehension, an empirically established postulation. Fluency comprehension deficiencies are generally known as a child's condition reading inability. This view is also backed by scholarly research. Most students with reading difficulties have been lenient and hard-working pupils. Such students often struggled to identify a word, and had to do without reading sometimes to recognize words, or to find 
different forms or morphemes of syllables by means of structural analysis. Given that fluency plays a significant role in literacy, in particular in children with literacy impairments, scholars have stressed the importance of interventions for the enhancement of student fluency. This paper aims to research thoroughly, on the basis of these limitations, the effect of oral fluent reading approaches on primary students, who have difficulties reading a wide spectrum of clinical trials in classrooms.

\section{LITERATURE REVIEW}

Effective intervention strategies are important to tackle the academic problems of learners (Hodges, 2020; Peters, et al, 2019; Sanders, et al, 2019). Educators accept that successful approaches are essential for academic skills. What are the most successful instructional techniques and approaches for students? Which methods prove to be effective when applied in this paper to intellectually handicapped students? One of the most important academic criteria is learning skills. Students of poor reading skills sometimes reflect their skill levels; and for students with poor reading capacities, schools are more problematic (Jamshidifarsani, et al, 2019; Roberts, et al, 2020). As research shows, limited reading skills impede the student's living status, and can be a major disadvantage in finding professional opportunities (Reed, \& Gates, 2020; Dietrichson, et al, 2020). Moreover, reading is very closely linked to intelligence quotient alevel (IQ) and reading understanding. According to the American Association of Intellectual and Developmental Disabilities (AAIDD), the IQ rates of intellectually impaired students are considerably smaller than those of their usually developing peers, since this low level specifically clarifies the link between their reading difficulties (Havercamp \& Krahn, 2019; Atack, et al, 2019; Qian, et al, 2019). Reading is a complex task, which allows intellectually-disabled students to read a difficult process (DeCarlo, et al, 2019; Griffin, et al, 2019; Grigal, et al, 2019).

Tucker-Cohen, Heller, Alberto and Fredrick (2008), analyzing the utility and viability of the approach, described it as a decryptive three-stage process and employed it as a consistently delayed tool to teach students with mental challenges to read and decrypt words. Several samples were used, the number of words as the dependent variable and the autonomous three-stage decoding strategy. Five mentally-disabled students between the age of nine and fourteen found a three-stage, constantly decoding technique to strengthen their students' decoding capabilities and word reading. Allor, Mathes, Roberts, Jones and Champlin (2010) have studied for students with minor intellectual disabilities (IQ 40-55) the efficiency of a standardized read protocol in early learning and language skills. In the district of urban schools and a private school, there were 28 primary students from 10 state schools, who were placed on a random basis in an intervention group participating in small daily lectures given by research teachers and in a group with typical special education. Respondents were offered detailed regular lessons in limited groups of 1-4 patients for around 40 minutes a day. Six certified teachers with special training were hired to teach the students.

In quite a similar context, Van, Nakken, Nicolay, and Van Houten (2007) studied the impact of a program on the learning and implementation, for adults with mild intellectual disabilities, of textual integration (summary, questioning, and clarification) training program. The participants' IQs were between 45 and 69, and were assigned randomly either to the experimental group or to the control group. The curriculum contained 15 one-hour weekly lessons and techniques for the overview, interviewing, interpretation and compilation of data. They found that, the intervention system has had an important impact on adult understanding strategies. The learning system used in this research offers a strong basis for developing the abilities of adults in literacy. Nonetheless, Conners, Rosenquist, Sligh, Atwell and Kiser (2006) assessed the efficiency of phonological reading for students with intellectual disabilities. There were 40 students with reading problems, and the results showed that, there is a much better academic group than the control group. In the oral tutorial, the teaching team even received a bit more than the control group, and the party expected the sound after the lesson significantly better than the control group. The final conclusion was that, the participants had better reading abilities. After reviewing literature on education strategies for students with intellectual disabilities, a wide range of educational strategies have shown their ability to improve readers' skills. However, this study focuses on strategies that are not included in the literature review. 


\section{Research Questions}

Tailored with the bibliographic analysis of eight selected papers on the strategies for improving reading ability, this study aims to analyze and review the context, scope, and effectiveness of reading interventions in the improvement of reading skills of the students. It specifically aims to answer the following questions:

1. What research designs and interventions have previous authors used to improve students' reading skills?

2. What are the findings of previous studies?

3. What are the research gaps and limitations that one can identify in the existing literature?

4. What research directions can be established from the reviewed and synthesized research papers? Or, what is the point of departure of the current investigation?

\section{METHOD}

A number of sources are analyzed using terms, such as oral fluency, education, daily reading, choral reading, subsequent reading, and comprehension ability, as well as, pupil inability or incapacity to learn. Only peerreviewed papers have been published to analyze the impact of floating strategies on students with reading disabilities. The compilation of papers in the peer review process in which reviewing studies are closely reviewed assures that the findings follow the existing evidence-based requirements of fluency teaching. Therefore, for the materials to be checked, sources referenced in prior meta-analyzes and statistical articles examining fluent oral reading methods were analyzed. For each referenced article, links to the related papers were finally checked.

\section{RESULTS}

The result of the analysis is presented in this section. It can synthesize from the Table 1, that most of the studies selected were experimental-interventional studies on oral reading fluency. Most of the studies recommended that there is a dire need for further exploration of the topic on oral reading fluency particularly on different age groups, grade levels, reading practices, teacher-related, and student-related factors. While it is evidential that oral reading fluency is correlated to different variables like reading comprehension, and other reading skills and sub-skills. The data further implies the need to use other research designs like hybrid, or mixed, method research to deepen understanding of oral language fluency knowledge. The reading disabilities of students on oral fluency can, therefore, be properly addressed with appropriate reading interventional process.

The area of special education will continue to inspire various strategies that allow students with disabilities to learn how to improve their reading skills in the classroom. By understanding the strengths of different students, the players in this area will make proper educational evaluations. Nonetheless, students with intellectual disabilities vary based on their particular conditions. For this reason, researchers, teachers, and other staff in the area of special needs should learn more about how best to treat each pupil with a disability. There are many other items from this topic that can be brought into attention to help improve the world of special needs. This study will yield a valid or enhanced understanding of the differences between different learners. Education teachers with special needs will also be able to know the different programs and assessments that are given to pupils of different levels of education or classes. The classes help students learn how they can better improve their skills. It allows them to improve their reading skills, and, thus, increase their ability to read fluently, particularly if they are deaf. The findings of this study inform the methodology and the analysis on this subject with respect to the latest testing approaches that can be used to identifying solutions, and thereby addressing other impaired students with difficulties in fluent oral reading.

Table 1. showed the Literature Matrix of the Study

\begin{tabular}{|l|l|l|l|l|l|}
\hline & Author & Design & Subjects & Findings & Research Gap \\
\hline 1 & Flaum-Horvath, S., & Quasi & The & FLEX students & SRA FLEX Literacy can \\
& Marchand-Martella, & experimental & participants & reported higher & make substantial \\
& N. E., Martella, R. C., \& & research & who were & results from SRI & improvements \\
& Kauppi, C. (2017). & design & used in the & Lexile than the & in the reading of young \\
& Examining the Effects & & study were & reference & students who are \\
& of" SRA FLEX & & 241 students & community. & At risk of failure at \\
\hline
\end{tabular}




\begin{tabular}{|c|c|c|c|c|c|}
\hline & $\begin{array}{l}\text { Literacy" }{ }^{\circledR} \text { on } \\
\text { Measures of Lexile® } \\
\text { and Oral Reading } \\
\text { Fluency with At-Risk } \\
\text { Middle School } \\
\text { Readers. Journal of } \\
\text { At-Risk Issues, 20(1), } \\
1-9 .\end{array}$ & & $\begin{array}{l}\text { in grade } 7 \text { and } \\
\text { 8. Out of this } \\
\text { participant, } 44 \\
\text { were selected } \\
\text { to get Tier } 3 \\
\text { reading } \\
\text { support } \\
\text { because they } \\
\text { were } \\
\text { considered at } \\
\text { risk. }\end{array}$ & & $\begin{array}{l}\text { school. More research } \\
\text { is warranted } \\
\text { The validation } \\
\text { program for these } \\
\text { effects. }\end{array}$ \\
\hline 2 & $\begin{array}{l}\text { Stage, S. A., \& } \\
\text { Jacobsen, M. D. } \\
\text { (2001). Predicting } \\
\text { student success on a } \\
\text { state-mandated } \\
\text { performance-based } \\
\text { assessment using } \\
\text { oral reading fluency. } \\
\text { School psychology } \\
\text { review, 30(3), 407- } \\
419\end{array}$ & $\begin{array}{l}\text { descriptive } \\
\text { correlational } \\
\text { research } \\
\text { design. }\end{array}$ & $\begin{array}{l}\text { The } \\
\text { participants } \\
\text { were } 173 \text { and } \\
\text { came from one } \\
\text { elementary } \\
\text { school in } \\
\text { Puget Sound } \\
\text { area. The 4th } \\
\text { grade } \\
\text { student's } \\
\text { scores were } \\
\text { used and } \\
\text { among the } \\
\text { participants } \\
54 \% \quad \text { were } \\
\text { male while } \\
46 \% \quad \text { were } \\
\text { female } \\
\text { students. } \\
\text { There were } \\
173 \text { students, } \\
54 \% \text { male and } \\
46 \% \quad \text { female. } \\
\text { Eleven of the } \\
\text { students } \\
\text { received } \\
\text { special education } \\
\text { services. This } \\
\text { constituted } \\
\text { the entire } \\
\text { fourth grade. }\end{array}$ & 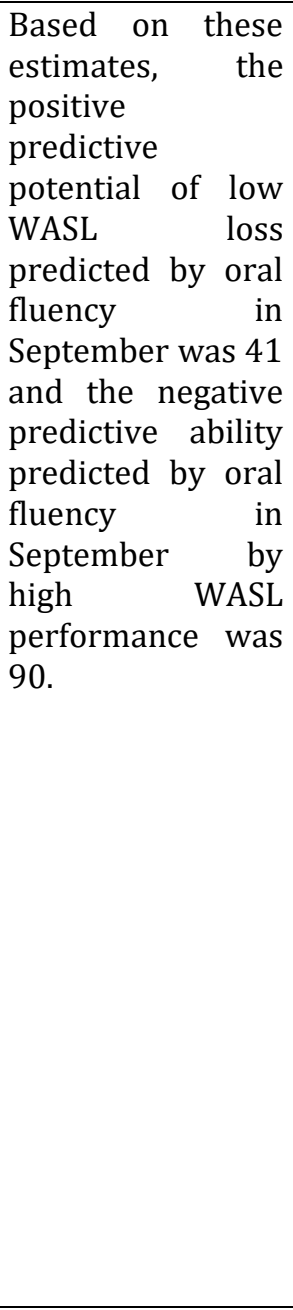 & $\begin{array}{l}\text { The limitations to this } \\
\text { study were due to the } \\
\text { fact that the } \\
\text { participants were } 4 \text { th } \\
\text { grade students, they } \\
\text { outperformed the } \\
\text { average student that } \\
\text { should be taking the } \\
\text { WASL reading } \\
\text { assessment. }\end{array}$ \\
\hline 3 & $\begin{array}{l}\text { Mellard, D., Woods, } \\
\text { K., \& Fall, E. (2011). } \\
\text { Assessment and } \\
\text { instruction of oral } \\
\text { reading fluency } \\
\text { among adults with } \\
\text { low literacy. Adult } \\
\text { basic education and } \\
\text { literacy journal, 5(1), } \\
\text { 3-14. }\end{array}$ & $\begin{array}{l}\text { Exploratory } \\
\text { study }\end{array}$ & $\begin{array}{l}\text { The } \\
\text { participants } \\
\text { included } 330 \\
\text { students } \\
\text { participating } \\
\text { in } 13 \\
\text { programs } \\
\text { under the } \\
\text { Midwest Adult } \\
\text { Education and } \\
\text { Family } \\
\text { Literacy Act. }\end{array}$ & $\begin{array}{l}\text { The four fluency } \\
\text { groupings in } \\
\text { structured } \\
\text { readability tests } \\
\text { indicate that } \\
\text { adults who read at } \\
\text { comparatively } \\
\text { accurate word } \\
\text { levels vary } \\
\text { substantially in } \\
\text { total words and } \\
\text { word mistakes. }\end{array}$ & $\begin{array}{l}\text { The limitation in this } \\
\text { study was the kind of } \\
\text { sample that was } \\
\text { selected were from one } \\
\text { region of the country } \\
\text { and were all adults } \\
\text { enrolled in Adult } \\
\text { Education program } \\
\text { programs. }\end{array}$ \\
\hline
\end{tabular}




\begin{tabular}{|c|c|c|c|c|c|}
\hline & & & $\begin{array}{l}\text { Eleven of the } \\
\text { members } \\
\text { failed to } \\
\text { attend. } \\
\text { Participants } \\
\text { must be aged } \\
\text { at least 16, } \\
\text { removed from } \\
\text { higher school } \\
\text { or be allowed } \\
\text { to work as an } \\
\text { immigrant in } \\
\text { the United } \\
\text { States to } \\
\text { obtain } \\
\text { payment for } \\
\text { membership. } \\
\text { Since this } \\
\text { research } \\
\text { concentrated } \\
\text { on literacy } \\
\text { and no gaps in } \\
\text { vocabulary, } \\
\text { we omitted } \\
\text { students who } \\
\text { enrolled in } \\
\text { Second } \\
\text { Language ( } \\
\text { ESL) English. }\end{array}$ & $\begin{array}{l}\text { These disparities } \\
\text { were irrespective } \\
\text { of the overall } \\
\text { capacity } \\
\text { measured. }\end{array}$ & \\
\hline 4 & $\begin{array}{lr}\text { Bolaños, D., Cole, R. } \\
\text { A., Ward, W. H., } \\
\text { Tindal, G. } & \text { A., } \\
\text { Hasbrouck, J., } & \text { \& } \\
\text { Schwanenflugel, P. J. } \\
\text { (2013). Human and } \\
\text { automated } \\
\text { assessment of oral } \\
\text { reading } & \text { fluency. } \\
\text { Journal } & \text { of } \\
\text { educational } & \\
\text { psychology, } & 105(4), \\
\text { 1142-1151 } & \end{array}$ & $\begin{array}{l}\text { Design and } \\
\text { Development } \\
\text { method of } \\
\text { Speech } \\
\text { recognition } \\
\text { system }\end{array}$ & $\begin{array}{l}313 \text { students } \\
\text { completed the } \\
\text { research at } \\
\text { four primary } \\
\text { schools in } \\
\text { Colorado's } \\
\text { Boulder Valley } \\
\text { School } \\
\text { District. Data } \\
\text { were gathered } \\
\text { from } 313 \text { first } \\
\text { to 4th year } \\
\text { students at } \\
\text { four elementary } \\
\text { elem } \\
\text { schools in } \\
\text { Colorado's } \\
\text { Boulder Valley } \\
\text { School District } \\
\text { (nine } \\
\text { classrooms). }\end{array}$ & $\begin{array}{l}\text { The conclusions } \\
\text { from this research } \\
\text { suggest that the } \\
\text { use of computer- } \\
\text { generated scores } \\
\text { is more likely to } \\
\text { expressively align } \\
\text { with human } \\
\text { beings than } \\
\text { human beings } \\
\text { agreed on. }\end{array}$ & $\begin{array}{l}\text { The main limitation of } \\
\text { the study was the small } \\
\text { number of students } \\
\text { used in the survey. }\end{array}$ \\
\hline 5 & $\begin{array}{l}\text { Hunley, S. A., Davies, } \\
\text { S. C., \& Miller, C. R. } \\
\text { (2013). The } \\
\text { relationship between } \\
\text { curriculum-based }\end{array}$ & $\begin{array}{l}\text { correlational } \\
\text { design }\end{array}$ & $\begin{array}{l}\text { The } \\
\text { participants } \\
\text { were chosen } \\
\text { voluntarily } \\
\text { and randomly. }\end{array}$ & $\begin{array}{lr}\text { there is } & \text { a } \\
\text { relationship } & \\
\text { between } & \text { oral } \\
\text { reading } & \text { fluency } \\
\text { measures } & \text { with }\end{array}$ & $\begin{array}{l}\text { The small and rural } \\
\text { sample that was used } \\
\text { in this study is the } \\
\text { biggest limitation. }\end{array}$ \\
\hline
\end{tabular}




\begin{tabular}{|c|c|c|c|c|c|}
\hline & $\begin{array}{l}\text { measures in oral } \\
\text { reading fluency and } \\
\text { high-stakes tests for } \\
\text { seventh } \\
\text { students. } \\
\text { online: research in } \\
\text { middle } \\
\text { education, } 36(5),\end{array}$ & & $\begin{array}{l}\text { After being } \\
\text { chose the CBM } \\
\text { passages were } \\
\text { given to the } 75 \\
\text { students so } \\
\text { that they } \\
\text { could read } \\
\text { them. The } \\
\text { students were } \\
\text { asked to read } \\
\text { aloud } \\
\text { individually, } \\
\text { three passages } \\
\text { for one minute } \\
\text { each. Students } \\
\text { read aloud } \\
\text { three passages } \\
\text { for one minute } \\
\text { each, and the } \\
\text { total number } \\
\text { of words read } \\
\text { correctly } \\
\text { served as oral } \\
\text { reading } \\
\text { scores. }\end{array}$ & $\begin{array}{l}\text { performance on } \\
\text { state assessments } \\
\text { for } 7 \text { th grade } \\
\text { students. }\end{array}$ & \\
\hline 6 & $\begin{array}{l}\text { Meeks, B. T., } \\
\text { Martinez, J., \& Pienta, } \\
\text { R. S. (2014). Effect of } \\
\text { edmark program on } \\
\text { reading fluency in } \\
\text { third-grade students } \\
\text { with disabilities. } \\
\text { International Journal } \\
\text { of Instruction, } 7(2) \text {, } \\
\text { 103-118. }\end{array}$ & $\begin{array}{l}\text { action } \\
\text { research } \\
\text { interventional } \\
\text { design } \\
\text { method and } \\
\text { experimental } \\
\text { research } \\
\text { design }\end{array}$ & $\begin{array}{l}\text { The } \\
\text { participants of } \\
\text { this study } \\
\text { were third- } \\
\text { grade students } \\
\mathrm{N}=6 \text { who } \\
\text { enrolled in the } \\
\text { elementary } \\
\text { school } \\
\text { between } \\
2009-2010 \text {. } \\
\text { The ages of } \\
\text { the participants } \\
\text { were between } \\
8 \text { to } 9 \text { years. }\end{array}$ & $\begin{array}{l}\text { The findings from } \\
\text { the study showed } \\
\text { that ERP plays a } \\
\text { significant role in } \\
\text { increasing the } \\
\text { student fluency }\end{array}$ & $\begin{array}{l}\text { Expanding the analysis } \\
\text { spectrum to include } \\
\text { Developmental } \\
\text { abilities that could } \\
\text { affect student fluence } \\
\text { would also improve } \\
\text { Opportunities to } \\
\text { strengthen our } \\
\text { understanding of best } \\
\text { practice in reading }\end{array}$ \\
\hline 7 & $\begin{array}{l}\text { Mellard, D., Woods, } \\
\text { K., \& Md Desa, Z. } \\
(2012) . \text { An oral } \\
\text { reading fluency } \\
\text { assessment for young } \\
\text { adult career and } \\
\text { technical education } \\
\text { students. Learning } \\
\text { disabilities research } \\
\text { \& practice, 27(3), } \\
\text { 125-135. }\end{array}$ & $\begin{array}{l}\text { multivariate } \\
\text { statistical } \\
\text { comparisons }\end{array}$ & $\begin{array}{l}\text { The } \\
\text { participants } \\
\text { that were used } \\
\text { in the study } \\
\text { were } 335 \text { Job } \\
\text { Corps } \\
\text { students, } \\
\text { however, only } \\
296 \text { students } \\
\text { managed to } \\
\text { compete the } \\
\text { survey who } \\
\text { two-third } \\
\text { were women }\end{array}$ & $\begin{array}{l}\text { The results } \\
\text { showed that a } 2 \\
\text { minute two- } \\
\text { dimension Oral } \\
\text { Reading Fluency } \\
\text { (ORF) assessment } \\
\text { can be utilized in } \\
\text { the creation of 4- } \\
\text { distinct groups of } \\
\text { students. }\end{array}$ & $\begin{array}{l}\text { Some of the limitations } \\
\text { was that the } \\
\text { researchers failed to } \\
\text { generalize their results } \\
\text { to the national } \\
\text { adolescent and adult } \\
\text { populations instead } \\
\text { they focused on young } \\
\text { adults. }\end{array}$ \\
\hline
\end{tabular}




\begin{tabular}{|c|c|c|c|c|c|}
\hline & & & $\begin{array}{l}\text { and the rest } \\
\text { male students. }\end{array}$ & & \\
\hline 8 & $\begin{array}{l}\text { Piper, B., \& } \\
\text { Zuilkowski, S. S. } \\
\text { (2015). Assessing } \\
\text { reading fluency in } \\
\text { Kenya: oral or silent } \\
\text { assessment? } \\
\text { International review } \\
\text { of education, 61(2), } \\
\text { 153-171. }\end{array}$ & $\begin{array}{l}\text { baseline } \\
\text { assessment, } \\
\text { random } \\
\text { sample, } \\
\text { descriptive- } \\
\text { evaluate } \\
\text { research } \\
\text { design }\end{array}$ & $\begin{array}{l}\text { The } \\
\text { participants } \\
\text { included } 1541 \\
\text { class } 2 \text { pupils } \\
\text { with the mean } \\
\text { age of } 8.1 \\
\text { years. There } \\
\text { were } 50 \\
\text { percent male } \\
\text { pupils and } 50 \\
\text { percent } \\
\text { female pupils. } \\
\text { Among first- } \\
\text { graders, } \\
\text { reading ability } \\
\text { was so low } \\
\text { that there was } \\
\text { essentially no } \\
\text { variation in } \\
\text { oral or silent } \\
\text { reading rates. }\end{array}$ & $\begin{array}{l}\text { There are no } \\
\text { statistically } \\
\text { substantial } \\
\text { variances } \\
\text { between silent } \\
\text { and oral reading } \\
\text { rates in either } \\
\text { English }\end{array}$ & $\begin{array}{l}\text { No literature shows } \\
\text { that silent reading is an } \\
\text { effective way to } \\
\text { maximize reading } \\
\text { rates. }\end{array}$ \\
\hline
\end{tabular}

Findings from this work can have impacts on the teachers, and on the classroom environments. First of all, teachers handle students with different personalities and abilities, and based on this, these findings can assist them in knowing how best to deal with the learners. For example, a particular test may not work for all learners, but to specific ones. At the end, teachers will provide proper assessments of students depending on their level of performance. Additionally, the findings are also effective in the management of the learning environment, which is the classroom. Teachers are able to make a distinction among learners depending on their abilities in the classroom. Also, it will enable teachers to determine the correct literacy programs that can be given to learners according to their abilities. Moreover, they will learn more about the effective assessment methods that can be used to determine the performance of learners.

The findings above discussed would help assess reading fluency, but it would not have the necessary resources or training required to deal with this child. It is well-established that, a student requires to be taught in a different manner, more suitable to the speed of their understanding of things, but a child psychologist and specialist educator would be required in school premises in order to help provide the child with a socially and emotionally viable environment to feel confident and learn things better. It will help ensure that, the student with a disability should not miss out on the education facility despite his or her treatment and condition.

One of the assessments that have been conducted relates to whether literacy levels in schools can be administered either orally or silently. It is evident that there are no variances that are realized on whether a person reads through an oral or silent means. In reading some texts in English and Kiswahili languages, there were not any statistical substantial variances that were realized in the oral readings. Although, there quite some slight deviation reading Kiswahili texts. Perhaps, it is because the Kiswahili language is known by a few students who were doing the test. The assessment of literacy levels among the disabled has proved to be hard to find on the side of teachers, therefore, fluent oral readings have been used by teachers to distinguish reading abilities of students in technical institutions.

The fluency of reading as done by students may be influenced by various educational programs. For example, ERP programs are very influential in raising the level of fluency among students, who engage in reading activities (Meeks, Martinez \& Pienta, 2014). Such programs, when administered to learners with various learning disabilities, they become significant in enhancing the reading ability of learners. It exposes them to regular reading exercises and with time, the learners increase their fluency in oral readings (Meeks, Martinez \& Pienta, 2014). The attitudes that children form towards these programs will determine their interests in wanting to know more about oral reading skills. Also, state tests are significant in increasing the 
ability of learners to acquire more skills in reading fluently (Stage \& Jacobsen, 2001). Tests should be provided to learners depending on their abilities. For example, tests given to the fourth year learners ought to be different from the rest, because they over-performed. The performance of the learners would be based on the ability of each and every student to, that is, in terms of their intellectual capacity of doing the tests. Assessments of oral reading can also be administered either through human means or computer automated means. The results of these two show that, automated assessment is more effective, for it yields accurate assessment through the inbuilt speech recognition devices and automated learning systems (Bolanos et.al, 2013).

Another finding on oral reading is based on the number of errors made while reading and the total word count (Mellard, Woods \& MdDesa, 2012). The effectiveness of fluent oral reading of an individual is determined, or may be affected, by the errors committed in reading in comparison to the whole text being read (Mellard, Woods \& Fall, 2011). Errors may occur, because a particular learner may lack some of the fundamental, or basic, principles that can help in learning to know more about how fluently an individual can be able to read. It is the availability of the fundamental abilities that may guide the learners to improving their reading abilities (Mellard, Woods \& Fall, 2011). This finding, nevertheless, depicts the limits that are related to the reliance on any particular component, or measure, of reading abilities. Moreover, students with learning disabilities can as well improve their ability to read depending on the appraisals they receive from their teachers. The more a learner receives appraisals, the more effective he or she can become in reading fluently. As is quite apparent, published programs have an impact on the ability of students to read fluently. This is evident from the outcomes of the literacy programs offered to learners in the middle school. Therefore, the ability of learners to read fluently is, in essence, dependent on many factors, such as the tests they are constantly given.

\section{CONCLUSION AND RECOMMENDATIONS}

As has been identified and discussed in this paper, assessment of reading fluency among learners with disabilities may be done through various ways. For instance, well-set out literacy programs and tests at various levels of learning help improve learners' abilities to read more fluently. Teachers and other stakeholders of special needs education have the advantage to learn more from these findings in their quest to build their field stronger; possibly because, these findings result in more implications to learning and research, thus providing a basis for improvement and development. As the paper has indicated, the learning environment for students with special needs is improved through the above programs when granted to them, and in this way, they acquire the ability to try and read fluently like other normal learners can do.

\section{Future Research Directions}

This study postulates the following research questions for future research directions of inquiry: (1) Do oral reading procedures improve the fluency of oral reading and understanding of students, who have difficulty reading in Saudi Arabia? (2) What are the salient features and successful steps that promote these reading results in the Saudi context? Findings promote the use of daily text reading for students with lecture problems to build ORFs. The most effective approaches were individually carried out using a skilled model of fluent word reading and accuracy. Findings also point to three comprehension gaps: (1) effective interventions other than repetitive readings; (2) prosody results of ORF therapies; and (3) sustainable performance. Future research work could investigate the aforementioned areas in great detail and possibly propose more effective ways of addressing the reading challenges discussed in this article. Such analyses could tackle the issue of whether or not the problem of the study is gender-oriented. The reading challenges of students from different background could also be studied and the results would certainly be of great use to all those interested in this field of study.

\section{Limitations}

The present study is only limited to eight selected papers. Further studies should include a decade-long synthesis of scholarly papers taking into account the continental, national and cultural reading dimensions. In such a way, it will produce a clearer evaluation and assessment of reading strategies, providing a comprehensive critical assessment of existing studies. In addition, articles from reviews may identify potential areas for further exploration, and from existing data they sometimes draw new conclusions, as well. 


\section{REFERENCES}

Allor, J. H., Mathes, P. G., Roberts, J. K., Jones, F. G., \& Champlin, T. M. (2010). Teaching students with moderate intellectual disabilities to read: An experimental examination of a comprehensive reading intervention. Education and training in autism and developmental disabilities, 3-22.

Atack, L., Verseghy, J., Maher, J., Herie, M., Poirier, M., MacNeil, F., \& Grimley, M. (2019). An Emerging model for semi-independent living for persons with intellectual and developmental disabilities. Inclusion, 7(1), 57-70.

Bolaños, D., Cole, R. A., Ward, W. H., Tindal, G. A., Hasbrouck, J., \& Schwanenflugel, P. J. (2013). Human and automated assessment of oral reading fluency. Journal of educational psychology, 105(4), 1142-1151

DeCarlo, M. P., Bogenschutz, M. D., Hall-Lande, J. A., \& Hewitt, A. S. (2019). Implementation of self-directed supports for people with intellectual and developmental disabilities in the United States. Journal of Disability Policy Studies, 30(1), 11-21.

Dietrichson, J., Filges, T., Klokker, R. H., Viinholt, B. C., Bøg, M., \& Jensen, U. H. (2020). Targeted school-based interventions for improving reading and mathematics for students with, or at risk of, academic difficulties in Grades 7-12: A systematic review. Campbell Systematic Reviews, 16(2), e1081. disabilities. Intervention in school and clinic, 52(1), 34-38.

Flaum-Horvath, S., Marchand-Martella, N. E., Martella, R. C., \& Kauppi, C. (2017). Examining the Effects of" SRA FLEX Literacy" ${ }^{\circledR}$ on Measures of Lexile ${ }^{\circledR}$ and Oral Reading Fluency with At-Risk Middle School Readers. Journal of At-Risk Issues, 20(1), 1-9.

Griffin, M. M., Fisher, M. H., Lane, L. A., \& Morin, L. (2019). In their own words: perceptions and experiences of bullying among individuals with intellectual and developmental disabilities. Intellectual and developmental disabilities, 57(1), 66-74.

Grigal, M., Papay, C., Smith, F., Hart, D., \& Verbeck, R. (2019). Experiences that predict employment for students with intellectual and developmental disabilities in federally funded higher education programs. Career Development and Transition for Exceptional Individuals, 42(1), 17-28.

Havercamp, S. M., \& Krahn, G. L. (2019). What matters in population health and how we count it among people with intellectual and developmental disabilities. Intellectual and Developmental Disabilities, 57(5), 347-356.

Hunley, S. A., Davies, S. C., \& Miller, C. R. (2013). The relationship between curriculum-based measures in oral reading fluency and high-stakes tests for seventh grade students. RMLE online: research in middle level education, 36(5),

Jamshidifarsani, H., Garbaya, S., Lim, T., Blazevic, P., \& Ritchie, J. M. (2019). Technology-based reading intervention programs for elementary grades: An analytical review. Computers \& Education, 128, 427-451.

Meeks, B. T., Martinez, J., \& Pienta, R. S. (2014). Effect of Edmark program on reading fluency in third-grade students with disabilities. International Journal of Instruction, 7(2), 103-118.

Meeks, B. T., Martinez, J., \& Pienta, R. S. (2014). Effect of edmark program on reading fluency in third-grade students with disabilities. International Journal of Instruction, 7(2), 103-118.

Mellard, D., Woods, K., \& Fall, E. (2011). Assessment and instruction of oral reading fluency among adults with low literacy. Adult basic education and literacy journal, 5(1), 3-14.

Mellard, D., Woods, K., \& Fall, E. (2011). Assessment and instruction of oral reading fluency among adults with low literacy. Adult basic education and literacy journal, 5(1), 3-14.

Mellard, D., Woods, K., \& Md Desa, Z. (2012). An oral reading fluency assessment for young adult career and technical education students. Learning disabilities research \& practice, 27(3), 125-135.

Mellard, D., Woods, K., \& Md Desa, Z. (2012). An oral reading fluency assessment for young adult career and technical education students. Learning disabilities research \& practice, 27(3), 125-135.

Peters, J. L., De Losa, L., Bavin, E. L., \& Crewther, S. G. (2019). Efficacy of dynamic visuo-attentional interventions for reading in dyslexic and neurotypical children: A systematic review. Neuroscience \& Biobehavioral Reviews, 100, 58-76.

Piper, B., \& Zuilkowski, S. S. (2015). Assessing reading fluency in Kenya: oral or silent assessment? International review of education, 61(2), 153-171.

Piper, B., \& Zuilkowski, S. S. (2015). Assessing reading fluency in Kenya: oral or silent assessment? International review of education, 61(2), 153-171. 
Qian, X., Larson, S. A., Tichá, R., Stancliffe, R., \& Pettingell, S. L. (2019). Active support training, staff assistance, and engagement of individuals with intellectual and developmental disabilities in the United States: Randomized controlled trial. American journal on intellectual and developmental disabilities, 124(2), 157-173.

Reed, D. K., \& Gates, C. (2020). Don't fail to plan for summer reading interventions. Preventing School Failure: Alternative Education for Children and Youth, 64(3), 223-229.

Roberts, G. J., Cho, E., Garwood, J. D., Goble, G. H., Robertson, T., \& Hodges, A. (2020). Reading interventions for students with reading and behavioral difficulties: A meta-analysis and evaluation of co-occurring difficulties. Educational Psychology Review, 32(1), 17-47.

Roberts, G. J., Cho, E., Garwood, J. D., Goble, G. H., Robertson, T., \& Hodges, A. (2020). Reading interventions for students with reading and behavioral difficulties: A meta-analysis and evaluation of co-occurring difficulties. Educational Psychology Review, 32(1), 17-47.

Rubin, D. I. (2016). Growth in oral reading fluency of Spanish ELL students with learning

Sanders, S., Losinski, M., Parks Ennis, R., White, W., Teagarden, J., \& Lane, J. (2019). A Meta-Analysis of SelfRegulated Strategy Development Reading Interventions to Improve the Reading Comprehension of Students With Disabilities. Reading \& Writing Quarterly, 35(4), 339-353.

Stage, S. A., \& Jacobsen, M. D. (2001). Predicting student success on a state-mandated performance-based assessment using oral reading fluency. School psychology review, 30(3), 407-419.

Stage, S. A., \& Jacobsen, M. D. (2001). Predicting student success on a state-mandated performance-based assessment using oral reading fluency. School psychology review, 30(3), 407-419

Tucker Cohen, E., Wolff Heller, K., Alberto, P., \& Fredrick, L. D. (2008). Using a three-step decoding strategy with constant time delay to teach word reading to students with mild and moderate mental retardation. Focus on Autism and Other Developmental Disabilities, 23(2), 67-78. 